\title{
Defending Korematsu?: Reflections on Civil Liberties in Wartime
}

Mark V. Tushnet

Georgetown University Law Center, tushnet@law.georgetown.edu

Copyright 2003 by The Board of Regents of the University of Wisconsin System; Reprinted by permission of the Wisconsin Law Review. Permitted use is limited to the work described above and does not include the right to grant to others permission to photocopy or otherwise reproduce this material except for copies permitted under the Copyright Act.

This paper can be downloaded free of charge from:

https://scholarship.law.georgetown.edu/facpub/246

2003 Wis. L. Rev. 273-307 (2003)

This open-access article is brought to you by the Georgetown Law Library. Posted with permission of the author. Follow this and additional works at: https://scholarship.law.georgetown.edu/facpub

Part of the Civil Rights and Discrimination Commons, and the Jurisprudence Commons 


\title{
GEORGETOWN LAW Faculty Publications
}

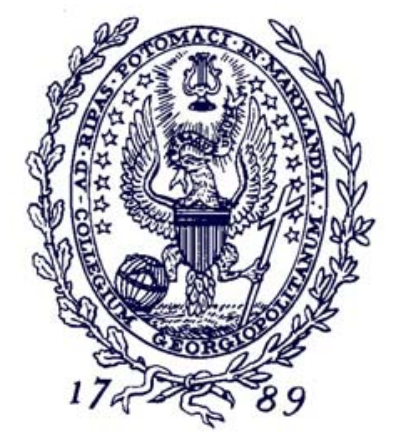

February 2010

\section{Defending Korematsu?: Reflections on Civil Liberties in Wartime*}

\author{
2003 Wis. L. Rev. 273-307 (2003) \\ Mark V. Tushnet \\ Professor of Law \\ Georgetown University Law Center \\ tushnet@law.georgetown.edu \\ This paper can be downloaded without charge from: \\ Scholarly Commons: http://scholarship.law.georgetown.edu/facpub/246/ \\ SSRN: http://ssrn.com/abstract $=368323$

\footnotetext{
Posted with permission of the author

* Copyright 2003 by The Board of Regents of the University of Wisconsin System; Reprinted by permission of the Wisconsin Law Review.
} 


\title{
DEFENDING KOREMATSU?: REFLECTIONS ON CIVIL LIBERTIES IN WARTIME
}

\author{
MARK TUSHNET* \\ INTRODUCTION
}

Writing in 1945 shortly after the end of World War II, Yale Law School professor Eugene Rostow described recently decided cases upholding the detention of Japanese American citizens as a "disaster." They deserved that description, Rostow believed, because " $[t]$ he course of action which we undertook was in no way required or justified by the circumstances of the war." ${ }^{2}$ For Rostow, "[t]he internment of the West Coast Japanese is the worst blow our liberties have sustained in many years. ${ }^{33}$

Rostow's criticism of Korematsu v. United States ${ }^{4}$ has become the common wisdom. Indeed, it has been generalized into an observation about the typical response of the U.S. government to perceived national security needs in wartime. The Latin phrase, inter arma silent leges, which literally means that in times of war law is silent, has been translated to mean that in wartime the U.S. government frequently adopts policies that are simultaneously exaggerated responses to real security threats and substantial restrictions on civil liberties. ${ }^{5}$ As David Cole has put it, "there is reason to think that as a general matter im times of crisis, we will overestimate our security needs and discount the value of liberty." And, according to Justice William J. Brennan, "After each perceived security crisis ended, the Umited States has remorsefully realized that the abrogation of civil liberties was unnecessary. But it has

* Carmack Waterhouse Professor of Constitutional Law, Georgetown University Law Center. 1 would like to thank members of the faculty of the University of Wisconsin Law School, David Abraham, T. Alexander Aleinikoff, Paul Brietzke, Wayne Moore, Richard Pildes, Peter Schuck, and Louis Michael Seidman for their comments on a draft of this Article, and Matthew Kilby for his invaluable research assistance.

1. Eugene Rostow, The Japanese American Cases-A Disaster, 54 YALE L.J. 489 (1945).

2. Id. at 489.

3. Id. at 490 .

4. 323 U.S. 214 (1944).

5. See, e.g., William H. Rehnquist, All the laws But One: Civil LIBERTIES IN WARTIME 224 (1998).

6. David Cole, Enemy Aliens, 54 StAN. L. Rev. 953, 955 (2002). 
proven unable to prevent itself from repeating the error when the next crisis came along."

This Article examines that observation, using Korematsu as a vehicle for refining the claim and, I think, reducing it to a more defensible one. Part I opens my discussion, providing some qualifications to the broad claim about threats to civil liberties in wartime. Part II then deals with Korematsu and other historical examples of civil liberties in wartime. It identifies a pattern in those examples and provides a sketch of a social theory that might account for the pattern. Part III describes, in relatively optimistic terms, a process of social learning in which past examples of what come to be understood as incursions on civil liberties progressively reduce the scope of civil liberties violations in wartime. Part IV raises jurisprudential questions about the role of emergency powers in liberal constitutions. In the end, I "defend" Korematsu in the perhaps ironic sense that Korematsu was part of a process of social learning that both dimimishes contemporary threats to civil liberties in our present situation and reproduces a framework of constitutionalism that ensures that such threats will be a permanent part of the constitutional landscape.

\section{SOME QUALIFICATIONS}

The claim about exaggerated responses needs to be stated with some precision. It consists of three assertions. First, officials typically overreact to threats to national security, describing them to the public and to themselves as more severe than those threats truly are. Second, officials typically develop policy responses to threats to national security that are not well designed to reduce the threats. ${ }^{8}$ And, third, one feature of the bad policy design is that the policies typically threaten established civil liberties. As Rostow put it, the government surely has "the power

7. William J. Brennan, Jr., The Quest to Develop a Jurisprudence of Civil Liberties in Times of Security Crises, 18 ISR. Y.B. HUM. RTS. 11, 11 (1988), quoted in Oren Gross, Cutting Down Trees: Law-Making Under the Shadow of Great Calamities, in THE SECURITY OF Freedom: ESSAYS ON CANAdA'S ANTI-TeRrorism BILL 39, 40 (Ronald J. Daniels et al. eds., 2001) [hereinafter THE SECURTY OF FREEDOM].

8. Stephen Schulhofer calls the policies that are subject to this concern bad compromises. STEPHEN J. SCHULHOFER, THE ENEMY WITHIN: INTELLIGENCE GATHERING, LAW ENFORCEMENT, AND CiVIL Liberties IN THE WAKE OF SEPTEMBer 11 , at 3 (2002). It is important to emphasize that the second claim is independent of the first. That is, the second claim is not simply that the policy responses are not well designed to reduce exaggerated threats to national security, but that they are not well designed to reduce the real threats. Often, the first claim obscures the second. After all, how could a policy be well designed to address an exaggerated threat? Good design necessarily requires accurate identification of the threat. 
to wage war successfully . . . [b]ut it is the power to wage war, not a license to do unnecessary and dictatorial things in the name of the war power."

\section{A. General Challenges to the Claim of Exaggerated Response}

Judge Richard Posner's recent reaction to the claims about exaggerated responses provides a useful point of entry to my discussion. Judge Posner focuses on the first component of the claims, that officials typically exaggerate risks. According to Judge Posner:

It will be argued that the lesson of history is that officials habitually exaggerate dangers to the nation's security. But the lesson of history is the opposite. It is because officials have repeatedly and disastrously underestimated these dangers that our history is as violent as it is. Consider such underestimated dangers as that of secession, which led to the Civil War; of a Japanese attack on the United States, which led to the disaster at Pearl Harbor; of Soviet espionage in the 1940s, which accelerated the Soviet Union's acquisition of nuclear weapons and emboldened Stalin to encourage North Korea's invasion of South Korea; of the installation of Soviet missiles in Cuba, which precipitated the Cuban missile crisis; . . . of the Tet Offensive of 1968; of the Iranian revolution of 1979 and the subsequent taking of American diplomats as hostages . . . ${ }^{10}$

Judge Posner makes this observation in the context of a discussion of civil liberties in wartime, and-in that context-it is a bit peculiar. One might quibble with some of his historical claims, ${ }^{11}$ but the more interesting point is that many of his examples are quite removed from the question of domestic civil liberties in wartime. Perhaps U.S. officials did underestimate the risk that the Soviet Union would install missiles in Cuba or the risk that radical Islamists would overthrow the Shah of Iran, but it is quite hard to identify domestic programs (or investigations) that could have been undertaken to dimimish the

9. Rostow, supra note 1, at 530 (emphasis added).

10. Richard A. Posner, The Truth About Our Liberties, RESPONSIVE Community, Summer 2002, at 4,5 .

11. It is not clear to me, for example, that anyone underestimated the risk that President Lincoln's election would lead to secession (or the risk that secession would lead to war). 
assertedly underestimated risks. ${ }^{12}$ In a sense, then, Judge Posner's attempt to refute the common claim about threats to civil liberties in wartime exemplifies the cast of mind that produces those threats.

A recent paper by Professors Lee Epstein, Jeffrey Segal, and Gary King offers a different critique of the overall claim. ${ }^{13}$ Their analysis focuses on the third component of the claim, that official reactions to national security threats in wartime typically violate established notions of civil liberties. Epstein and her colleagues provide a quantitative analysis of Supreme Court cases dealing with civil rights and civil liberties from 1941 to 1999 , comparing the rate of government success defending against such claims during times of war (as they define those periods) and during other times. ${ }^{14}$ Their results are striking: The government's success rate during wartime is lower than its success rate in peacetime. They find a slight tendency in wartime for the government to prevail more often in cases involving protest demonstrations, internal security, and conscientious objection, but a slight tendency for aliens to prevail more often. They also examine whether the government prevails more often in what they call "salient" cases, which they define as cases that receive front-page coverage in The New York Times. During wartime, "the Court supported the party

12. As Jack Balkin puts it, "Our lack of preparedness for Pearl Harbor resulted from failures of diplomatic and military intelligence overseas, not too many writs of habeas corpus or an overindulgent constabulary. No one thinks that Miranda v. Arizona caused the Tet Offensive or the Iranian revolution." Jack M. Balkin, The Truth About Our Institutions, Responsive Community, Fall 2002, at 92, 94. Perhaps one could argue that the U.S. government's limited response to the domestic anti-war movement encouraged the North Vietnamese to launch the Tet Offensive, although it would be helpful to have evidence from the North Vietnamese to that effect. But, I would add, suppressing the anti-war movement to the point where the North Vietnamese might not have been encouraged would have required quite large-scale government action of a sort that would legitimately raise questions about infringements on civil liberties. Put another way, I suggest that a government that accurately assessed the risks of an offensive like the one that occurred, and believed that suppressing domestic dissent could reduce those risks, would have had to engage in what would also have been regarded as real intrusions on civil liberties. This is, I think, contrary to the point Judge Posner wishes to make.

13. Lee Epstein, Jeffrey A. Segal, \& Gary King, During War is Law "Silent"?: An Investigation of Supreme Court Decision Making in Times of Crisis (Oct. 11,2002 ) (prepared for presentation at Georgetown University Law Center) (on file with author). This paper is a work-in-progress, and Professor Epstein has informed me that the authors have refined and qualified their analysis in light of critiques they have received.

14. The authors distinguish between times of war strictly defined, wartime and periods of "major conflicts," and periods when there may still be what they call a "rally effect," a surge in presidential popularity due to some international event. These distinctions are unimportant for present purposes. 
alleging a violation in $60.4 \% \ldots$; that figure for cases resolved in the absence of a war is somewhat (though not significantly) lower, $56.3 \%$." 15

These results clearly mean that one must temper the strongest claims made about the silence of law during wartime. Yet, one can still harbor doubts about the meaning of the statistics Epstein and her colleagues analyze. ${ }^{16}$ With a qualification to be noted, their analysis treats every case as equally important as a test of the claim about the silence of the law during wartime. So, "for example," they write, "almost every account of judicial behavior during international altercations points to Korematsu as an illustration of the crisis thesis in action. Just the year before, however (and while the United States was at war with Germany), in Taylor v. Mississippi the Court ruled in favor of individuals convicted for making anti-war and -draft statements." 17 An analysis that gives equal weight to Korematsu and Taylor seems to rest on flawed assumptions. ${ }^{18}$ Epstein and her colleagues seek to address this concern by measuring government success rates in "salient" cases. Here too their measure seems inadequate. Cases receive frontpage treatment in The New York Times for many reasons, not all of which support the inference that such placement demonstrates that each case on the front page is equally important. For example, it may have been a slow news day, or the Times may have assumed that something about the Supreme Court has to appear on the front page whenever the Court acts, ${ }^{19}$ or the Times' editors may choose to place pro-civil liberties decisions on the front page to demonstrate the nation's commitment to

15. Epstein, Segal, \& King, supra note 13, at 13 .

16. In addition to the questions raised in the text, one might note (1) that the analysis offered by Epstein and her colleagues does not take account of the possibility that the Court might deny review during wartime in cases raising truly troubling civil liberties questions, then grant review in other cases raising the same questions and decide them against the government after the war ends, and (2) that the category civil liberties may be too broad to capture the critics' concerns, particularly because some policies that raise the most acute concerns simply are not put in place during peacetime.

17. Epstein, Segal, \& King, supra note 13, at 7.

18. Similarly, as Mark Graber points out in a forthcoming work, Epstein and her colleagues count Griswold v. Connecticut, 381 U.S. 479 (1965), as a pro-civil liberties decision rendered in wartime, which is accurate given their definitions. Yet, I doubt that those who claim that wartime places civil liberties under stress have cases "like" Griswold in mind when making that claim. Rather, their claim is that civil liberties cases raising claims related to wartime conditions are less likely to succeed than would similar claims made in peacetime. Obviously, identifying the class of "related to" cases will be difficult, but some such effort seems necessary before one can use the quantitative techniques favored by Epstein and her colleagues.

19. That assumption might have been particularly strong when the Court confined its decision days to Mondays, a practice it abandoned in the 1970 s. 
civil liberties even in wartime or even precisely in order to combat those who criticize the nation for ignoring civil liberties in wartime. Notably, the last of these possibilities suggests that the causal chain runs in the opposite direction from the one Epstein and her co-authors believe-not from inportance to appearing on the front page but rather from appearing on the front page to (ideological) importance.

Philip Klinkner and Rogers Smith, and Kim Lane Scheppele have made a broader argument supporting the proposition that some civil liberties might be advanced during wartime. ${ }^{20}$ Scheppele describes a phenomenon she calls "aversive constitutionalism," in which a nation develops its constitutional law by referring to examples of behavior in other nations that is said to be inconsistent with the first nation's constitutional values. ${ }^{21}$ For the United States, the other nation of course might well be one with which the Umited States is at war. So, for example, the second round of wartime flag-salute cases can be understood as the Supreme Court's defense of civil liberties on the ground that coercing expression is something our Nazi adversaries did. ${ }^{22}$ Klinkner and Smith identify circumstances under which racial equality has been advanced in the Umited States, and isolate wars of a certain type as a precondition for essentially any such advance. ${ }^{23}$ In wars against enemies with anti-egalitarian ideologies, political leaders can justify domestic sacrifices by asserting that the war is one to advance American values, including racial equality.

These arguments do not demonstrate that a qualified version of the argument about law's silence in wartime is unfounded. ${ }^{24}$ Still, the arguments are enough to caution us against asserting too strongly that every civil liberty is deeply at risk during wartime. ${ }^{25}$

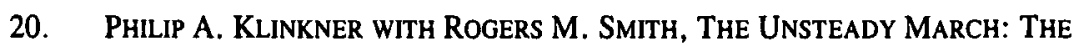
RISE AND DECLINE OF RACIAL EQUALITY IN AMERICA (1999); Kim Lane Scheppele, Aspirational and Aversive Constitutionalism: The Case for Studying Cross-Constitutional Influence Through Negative Models, 1 INT'L J. CONST. L. 296 (2003).

21. Scheppele, supra note 20, at 300.

22. See W. Va. State Bd. of Educ. v. Barnette, 319 U.S. 624 (1943).

23. KLINKNER \& SMITH, supra note 20, at 3-4.

24. In particular, advances in civil liberties in wartime may occur by expanding "our" liberties while contracting "theirs," with an attendant opportunity-and risk-of redefining who is the "we" and who is the "they" in the circumstances. For additional discussion, see infra text accompanying notes 89-90.

25. A different response to the general claim is that law is-or at least should be-as vocal during wartime as any other time. See, e.g., Aharon Barak, The Supreme Court, 2001 Term-Foreword, A Judge on Judging: The Role of a Supreme Court in a Democracy, 116 HARV. L. REv. 16, 150-53 (2002) (arguing that "[t]here is always law ... according to which the state must act"). Despite an overall assessment that courts have demonstrated "depressingly familiar shortcomings" in enforcing constitutional 


\section{B. When Is Wartime?}

Early statements by the Bush administration about the war on terrorism were to the effect that the war was one of indefinite duration. And, indeed, statements about the existence of a war on terrorism go back quite a long way. President Ronald Reagan's First Inaugural Address, delivered as the Iranian hostage crisis was ending, said that the United States would use "the will and moral courage of free men and wonien" as a "weapon" against "those who practice terrorism and prey upon their neighbors." ${ }^{26}$ The 1996 revision of the federal habeas corpus statute goes by the acronym AEDPA; the last letters stand for "Effective Death Penalty Act," while the first stands for "Antiterrorism."27

The already long duration of the "war on terrorism" suggests that we ought not think of it as a war in the sense that World War II was a war. It is, perhaps, more like a condition than a war-more like the war on cancer, the war on poverty, or, most pertinently, the war on crime. To say that law is silent during a more-or-less permanent condition is quite different fronı saymg that law is silent during wartime. Perhaps more accurately, the law that speaks when we are in a condition like the war on crime is simply different fron the law that speaks when we think we need not be especially concerned with crime.

Seeing the "war on terrorism" as a condition also helps us understand why there is sometimes concern about the enforcenient of civil liberties during wartime. Wars place civil liberties under strain for several reasons. Mobilizing for war requires a nation to displace its other domestic priorities, with the effect that the people cannot get from the government some of what they previously thought important. This niay generate a desire to end the war quickly, so that we can get on with our business. That desire, in turn, niay generate resentment at those who are thought to be prolonging the war-the enemy in the first instance, but domestic dissidents as well.

restrictions on the invocation and exercise of emergency powers, Venkat Iyer offers "some notable examples of judicial controls succeeding in moderating the wilder excesses of certain emergency regimes." VENKAT IYER, STATES OF EMERGENCY: THE INDIAN EXPERIENCE 62, 63 (2000) (describing decisions by courts in Argentina, Brazil, and South Africa).

26. See President Ronald Reagan, First Inaugural Address (Jan. 20, 1981), in InAugural AdDRESSES OF the PREsidents of THE United States 331 (1989).

27. Antiterrorism and Effective Death Penalty Act of 1996 (AEDPA), Pub. L. No. 104-132, 110 Stat. 1214 (codified as amended in scattered sections of $8,18,22,28$, 40 , and 42 U.S.C.). 
This dynamic may operate differently when the war is a condition, and particularly in connection with the current "war on terrorism." The Bush administration's official position is that one important means of combating terrorisin lies in the American people getting on with their lives and ignoring as best we can the threat of terrorism brought home. Because the "war on terrorism" does not require much sacrifice on an on-going basis from any of us, the war may not generate the resentments that place pressure on civil liberties. Further, at least so far, the "war on terrorism" has generated little domestic dissent. ${ }^{28} \mathrm{~A}$ low level of dissent might have two quite different consequences. A low level of dissent might allow the nation's majority to ignore-or tolerate-the dissidents, whose actions the majority could see as unimportant. Yet, a low level of dissent might allow the nation's majority to find actions taken against the dissidents to be entirely acceptable.

To the extent that the war on terrorism is a condition rather than a more traditional war, it seems clear that the proper response for legal analysis is to think through what the more-or-less permanent balance between liberty and security should be. ${ }^{29}$ Put another way, war-ascondition is a normal state of affairs, not an emergency in which extraordinary measures might be appropriate. ${ }^{30}$ And, the normal constitutional rules ought to apply in normal conditions.

\section{What Are Civil Liberties?}

Addressing Congress in December 1862, President Abraham Lincoln said, "The dogmas of the quiet past are inadequate to the stormy present. The occasion is piled high with difficulty, and we must rise with the occasion. As our case is new, so we must think anew, and act

28. The war in Iraq did generate substantial domestic dissent, but the war's quick termination may make it difficult for supporters of the war on terrorism to attribute later difficulties, if they occur, to domestic dissent.

29. In this connection, it might be worth noting the possibility that the most relevant retrospective evaluation of current policies might rest on the proposition that the United States was engaged in a war on terrorism whereas in retrospect it will seem that in fact the United States was experiencing a condition of terrorism. In Padilla ex rel. Newman v. Bush, Judge Michael Mukasey's discussion of the possibility that indefinite detention of a U.S. citizen as an enemy combatant might become "moot" may perhaps be understood as the Judge's recognition of the possibility that what is today perceived as a war will later become perceived as a condition, although there are other reasons one might have for thinking that a detention justified today might become unjustified in light of later events. See 233 F. Supp. 2d 564 (S.D.N.Y. 2002), adhered to upon reconsideration, 243 F. Supp. 2d 42 (S.D.N.Y. 2003).

30. See Gross, supra note 7, at 44 (" $[T]$ he governing paradigm is that of the 'normalcy-rule, emergency-exception.' "). 
anew. We must disenthrall ourselves, and then we shall save our country. ${ }^{\text {31 }}$ Lincoln elegantly put what has become a standard point about legal and constitutional analysis: Circumstances alter cases. That is, the constitutional doctrines developed in connection with commercial advertising or even political speech in ordinary times may not be appropriate in other circumstances.

The Supreme Court has recognized the point. Writing in the context of an economic rather than a military crisis, Justice Harlan Fiske Stone argued that constitutional law did not need to be displaced, but only properly interpreted, to deal effectively with the crisis. As he put it, "emergency does not create power, [but] emergency may furnish the occasion for the exercise of power." 32 And, just as emergency may create the occasion for the exercise of power, emergency may provide a justification for actions that would, absent the emergency, be unjustified intrusions on civil liberties. As Justice Holmes noted, "When a nation is at war many things that might be said in time of peace are such a hindrance to its effort that their utterance will not be endured so long as men fight and that no Court could regard them as protected by any constitutional right. ${ }^{33}$ Holmes might be read as expressing a resigned acceptance of the inevitable, but it is better to read him as asserting that what counts as a violation of free speech in peacetime is just different from what might count as a violation of free speech in wartime. ${ }^{34}$

And, this must be right. At the most abstract level, a nation's commitment to principles of free expression persists undiminished no matter what the circumstances. But, no one ever questions the abstract commitment anyway: Governments that prosecute someone for dissident speech never say that the prosecution is inconsistent with principles of free expression, but say instead that the speech at issue is not protected by those principles properly understood. The real question, then, is whether the scope of the particular civil liberty at issue is properly defined with reference to wartime conditions.

Here we can distinguish between two general approaches to the definition of constitutional rights: a balancing approach and a categorical approach. Plainly, wartime conditions are relevant when constitutional rights are defined by balancing competing interests. Balancing approaches, though, raise in acute form the concern about law's silence

31. President Abraham Lincoln, Annual Message to Congress (Dec. 1, 1862), in 5 The Collected Works of Abraham LinColn 518, 537 (Roy P. Basler ed., 1953).

32. Home Bldg. \& Loan Ass'n v. Blaisdell, 290 U.S. 398, 426 (1934).

33. Schenck v. United States, 249 U.S. 47, 52 (1919).

34. For one thing, Holnes was himself a member of a court that was at the very moment deciding whether the speech in question was constitutionally protected. 
in wartime. Judges no less than other government officials are susceptible to the pressures of events. Justice Robert Jackson made some astute observations about the war power that are applicable as well to the definition of constitutional rights with reference to wartime conditions:

[T]his vague, undefined and indefmable "war power" . . . usually is invoked in haste and excitement when calm legislative consideration of constitutional limitation is difficult. It is executed in a time of patriotic fervor that makes moderation unpopular. And, worst of all, it is interpreted by judges under the influence of the same passions and pressures. $^{35}$

Judges, one might fear, will undervalue some and overvalue other elements in the balance, and so define constitutional rights in a way that, on reflection, should be troubling.

Categorical approaches are designed to offset this tendency by screening out of consideration the features of the circumstances that are likely to induce nisjudgment. And, under some conditions, they may succeed in doing so, when the categorical rules address decision-makers who might not appreciate the importance of considerations thought to be peripheral to their more central tasks. Consider, for example, a categorical rule against torture by police officers. Judges might think that in the abstract they can imagine situations in which torture might be a valuable investigative technique. Judges might think that they must communicate rules effectively to police officers. They might also think that any verbal formulation of the (limited) circumstances in which torture might be acceptable is too likely to be misinterpreted in ways that would lead the officers to engage in torture more often than they should. The judges could then conclude that they should announce a categorical rule against torture despite their awareness that such a rule does not correspond to their own sense of what is acceptable.

Categorical approaches nake the most sense, then, when judges are designing rules for others to follow. Unfortunately, they do so in the form of precedents, that is, in the form of rules that they themselves are to follow. It takes a mind-set that is, I think, quite difficult to achieve for a person to rule out of consideration for himself or herself in the future something that the person today thinks plainly relevant to a

35. Woods v. Cloyd W. Miller Co., 333 U.S. 138, 146 (1948) (Jackson, J., concurring). 
decision. The difficulty in the context of defining constitutional rights in wartime is obvious. The circumstances of war are something like an elephant in the living room. Judges might agree that a categorical rule is desirable, but say that the rules simply differ in wartime. That is, they would take the category war as relevant to defining the applicable rule, and screen out other considerations. Alternatively, the judges might try to screen out the wartime circumstances in their formulation of the rule. But, try as they might, judges are quite unlikely to be able to ignore the elephant's presence. True, they might not explicitly mention the elephant in defining the categorical rule they invoke, but one can rightly be skeptical about any claim that the elephant played no part as they thought about what the rule should be.

What this means, though, is that one will be hard-pressed to say, in any voice other than an advocate's, that civil liberties are violated in wartime. Judges will test government actions against the Constitution. They may often find that the actions do not violate the Constitution, either because the judges place the wartime circumstances in the balance as they define constitutional rights or because they formulate categorical rules that take the fact of war as relevant to triggering one or another rule. It is not, then, that law is silent in wartime. Rather, it is that sometimes it speaks in tones that advocates of particular positions do not like. But, after all, how is that different from any other time?

\section{KOREMATSU AND THE EX ANTE PERSPECTIVE}

This Part explores a pattern in our responses to government actions taken in wartime, tries to explain that pattern, and previews a reasonably optimistic account of a process of social learning that takes the explanation seriously. The pattern is this: The government takes some action that its officials-and, frequently, the courts-justify by invoking national security. In retrospect, once the wartime emergency has passed, the actions, and their endorsement by the courts, come to be seen as unjustified in fact (that is, by the facts as they actually existed when the actions were taken). The explanation is this: The actions are taken under conditions of uncertainty, when the officials do not know how the war is going to turn out, but they are evaluated retrospectively in, as Justice Black put it, "calmer times," and often when the war has been won. ${ }^{36}$ The glow of success reflects backwards and affects our evaluations. ${ }^{37}$ The social learning is this: Knowing that government

36. Dennis v. United States, 341 U.S. 494, 581 (1951) (Black, J., dissenting); see also Schenck, 249 U.S. at 52.

37. The fancy description of this is hindsight bias. For an accessible 
officials in the past have in fact exaggerated threats to national security or have taken actions that were ineffective with respect to the threats that actually were present, we have become increasingly skeptical about contemporary claims regarding those threats, with the effect that the scope of proposed government responses to threats has decreased.

\section{A. The Pattern and Explanation: Ex Ante Decision, Ex Post Evaluation, and Ex Ante Knowledge}

As 1 have said, it is commonly asserted that wartime emergencies elicit policy responses that in retrospect are seen as unjustified. I will sketch the history that supports this assertion, making no claims that I can provide a comprehensive view either of the episodes I discuss or the entire sweep of U.S. history. ${ }^{38}$

The first period is the $1860 \mathrm{~s}^{39}$ President Abraham Lincoln suspended the writ of habeas corpus, obtaining congressional approval only after the event. He directed that military courts operate in areas threatened by Southern forces even though the civilian courts remained open. ${ }^{40}$ Sitting as a circuit judge, Chief Justice Roger Taney condemned the suspension of the writ, ${ }^{41}$ but the Suprene Court never ruled on the constitutionality of Lincoln's action. In February 1864, while the Civil War was still in progress, the Supreme Court denied that it had jurisdiction to review the constitutionality of military trials by the statutory route the defendant chose,$^{42}$ and then, in 1866 , after the war had ended, held that the military trials were unconstitutional. ${ }^{43}$ During Reconstruction, the Supreme Court evaded challenges to the

discussion, see Jeffrey J. Rachlinski, A Positive Political Theory of Judging in Hindsight, 65 U. CHI. L. REv. 571 (1998).

38. I am especially concerned that the common use of a few episodes might be misleading, and that examination of every period in which the United States (whether the government or the people) believed itself to be under significant external threat might disclose a far more random set of responses than the common story identifies.

39. Sometimes the story is told about the Civil War only, omitting Reconstruction. I think that doing so may lead one to give a bit too much credit to the Supreme Court, which was somewhat more receptive to challenges to executive actions taken during the Civil War than it was to challenges to Reconstruction, even though civil liberties concerns could have arisen in connection with both periods.

40. The classic overview of Lincoln's actions from a constitutional perspective is James G. Randall, Constitutional Problems Under Lincoln (rev. ed. 1963).

41. Ex parte Merryman, 17 F. Cas. 144, 147 (C.C.D. Md. 1861) (No. 9,487).

42. Ex parte Vallandigham, 68 U.S. (1 Wall.) 243, 251-52 (1863).

43. Ex parte Milligan, 71 U.S. (4 Wall.) 2 (1866). 
constitutionality of military reconstruction, ${ }^{44}$ although its 1869 decision in Texas $v$. White adopted a theory that simultaneously endorsed the Republican Party position that secession was illegal and cast some doubt on the legality of the Republican Party position on military reconstruction. ${ }^{45}$

The historical judgment on these events is ambivalent. Critics of Lincoln's actions make a strong case that Congress must authorize the suspension of the writ of habeas corpus before the President acts. And, continued military occupation of a pacified domestic territory seems inconsistent not only with federalism but with core constitutional concerns about civilian self-government. Yet, in both instances the practical imperatives of the circumstances, and the evident justness of the Northern cause, seen to support the legality of the government's actions. ${ }^{46}$

The second period typically referred to in discussions of civil liberties in wartime is the period near the end of World War I and extending imto the early 1920s, when-for a time-the Umited States provided support for anti-Soviet forces in the Russian Civil War. The U.S. Attorney General and state prosecutors brought charges against a large number of domestic radicals for seditious speech, essentially speech critical of the nation's wartime positions, ${ }^{47}$ and the Attorney General directed a round up of radical aliens, seeking their deportation. ${ }^{48}$ The Supreme Court upheld the use of laws making unlawful the criticism of government policy. The Court adopted the famous "clear and present danger" test in Schenck $v$. United States, ${ }^{49}$ but applied it relatively loosely, allowing juries to find a defendant guilty if the defendant's speech had a natural tendency to induce listeners to violate the laws being criticized. ${ }^{30}$ The Court continued to apply loose

44. See Ex parte McCardle, 74 U.S. (7 Wall.) 506 (1869); Georgia v. Stanton, 73 U.S. (4 Wall.) 50 (1868); Mississippi v. Johnson, 71 U.S. (4 Wall.) 475 (1867).

45. 74 U.S. 700,725 (1869) (describing the nation as "an indestructible Union, composed of indestructible States").

46. The considerations that lead some to find the government's actions in the 1860s lawful are among those that must be taken into account in evaluating claims about the necessity for constitutional emergency powers. See infra Part IV.

47. For a study of the sedition prosecutions, see RICHARD POLENBERG, Fighting Faiths: The Abrams CASE, the Supreme CoURT, ANd FreE SPEeCH (1987).

48. On the Palmer Raids and the 1920s Red Scare, see ROBERT K. MURRAY, RED SCARE: A STUDY OF NATIONAL HYSTERIA, 1919-1920 (1955), and REGIN SCHMIDT, RED SCARE: FBI AND THE ORIGINS OF ANTICOMMUNISM IN THE UNITED STATES, 1919$1943(2000)$.

49. 249 U.S. at 52 .

50. See, e.g., Abrams v. United States, 250 U.S. 616 (1919). 
First Amendment standards through the $1920 \mathrm{~s},{ }^{51}$ but, as we will see, later courts repudiated the Court's application of its First Amendment standards. ${ }^{52}$

The Japanese internment cases are the central examples of civil liberties violations during World War II, and for the moment I will simply note the immediate adverse response to the Supreme Court's decision in Korematsu, ${ }^{53}$ a response that has not changed since 1945.

During the hottest periods of the Cold War, the government brought prosecutions against members of the Communist Party. Government officials took various other adverse actions against inembers of the Party, people associated with the Party, and people of a general left-wing cast who were thought to be associated with the Party. In 1951 the Supreme Court upheld the convictions of the Party's inain leaders. ${ }^{54}$ It endorsed the "clear and present danger" test, restating it in a way seemingly more protective of expression. Chief Justice Vinson's plurality opinion expressly asserted that the dissenting views expressed by Justices Holmes and Brandeis in the cases of the 1920s were the ones later cases "inclined" toward..$^{55}$ Still, the Court did uphold the convictions.

Later in the 1950s the Court invoked the heightened standard to reverse convictions of the Party's second-line leaders, ${ }^{56}$ and developed related constitutional rules that made it harder for the government to impose sanctions on inere "fellow travelers." Its most important decision, for present purposes, allowed the government to convict a person for associating with a group that had both legal and illegal goals only if the government showed that the person was an "active" member who specifically intended to carry out the group's illegal goals. ${ }^{57}$ Again, this restatement occurred in an opimion upholding a conviction. Still later, in 1968, in the midst of anti-Vietnam war protests and aware of the significance of its decision for potential prosecutions of antiwar protestors, the Court further tightened the standard in Brandenburg $v$.

51. Whitney v. California, 274 U.S. 357 (1927); Gitlow v. New York, 268 U.S. 652 (1925).

52. I acknowledge, with some discomfort, that I am painting with a very broad brush here, and that a more complete account would distinguish among the types of law at issue in Schenck and Gitlow and would describe how a court might reasonably have thought the problems different.

53. See supra text accompanying notes 1-3.

54. Dennis, 341 U.S. at 516-17.

55. Id. at 507 .

56. Yates v. United States, 354 U.S. 298, 327 (1957).

57. Scales v. United States, 367 U.S. 203, 228-29 (1961). 
Ohio ${ }^{58}$ now allowing convictions only where advocacy of illegal action "is directed to inciting or producing imminent lawless action and is likely to incite or produce such action." 59

This quick survey indicates the pattern commonly attributed to the civil liberties implications of government policies in wartime: The government acts, the courts endorse or acquiesce, and-sooner or later-society reaches a judgment that the action was unjustified and the courts were mistaken. The retrospective critical view is a compound of two other judgments: that the threat to which the actions were responses was exaggerated, and that the responses were excessive in relation to the exaggerated threats (obviously) and even to the real threats that existed. So, for example, critics say that the Japanese internments were supposed to limit the possibility that Japanese Americans would engage in sabotage and espionage on the West Coast, but that there was a much smaller risk of sabotage and espionage from that community than policymakers thought. Or, they might acknowledge that the threats to the United States from Soviet espionage were substantial, but assert that prosecuting nembers of the U.S. Communist Party was a badly designed policy response to the threat of espionage, which would have been countered better by devoting investigative and prosecutorial resources instead to intensified scrutiny of people associated with embassies and consulates.

The critical reactions to policies made in wartime circumstances may be mistaken. The reason is that the reactions occur after the event, but policy-makers must act before the event. Even more, the reactions all have occurred after the United States succeeded in combating the wartime enemy, and usually under circumstances where there is no plausible case to be made that the actions in question-the Japanese internment, for example-actually played a significant role in the United States' success. The policy-makers were acting in real time, when they did not know that the United States would win the war and, even more, when they could not be sure of the size of the threats they were dealing with or of the effectiveness of various strategies to respond to these threats of uncertain size.

From the ex ante perspective of the policy-makers themselves, the actions they take might be entirely rational and ought not be criticized in retrospect. And, to the extent that we are concerned with developing a law that will guide policy-makers, we should be careful not to constrain them because of our hindsight wisdom-unless we are confident that the

58. 395 U.S. 444 (1969).

59. Id. at 447 . 
constraints we put in place really do respond only to tendencies to exaggerate uncertain threats or to develop ineffective policy responses to real ones.

Developing appropriate responses to decision-making under conditions of uncertainty may be less difficult than it might seem, though. The reason is that there is another feature of the pattern that I have not yet discussed. The ex ante defense of policy-makers assumes that they are doing the best they can to respond in conditions of uncertainty. The historical record rather strongly suggests that this assumption is often incorrect. Examination of the decision-making process in detail reveals quite often-perhaps almost always-that at the time the policies were chosen at least some of the relevant decisionmakers knew, and more should have known, that the policies they were adopting were either responses to exaggerated threats or likely to be ineffective in countering the real threats.

The evidence is clearest in connection with the Japanese internment. ${ }^{60}$ There, General John L. DeWitt, the West Coast military commander, was a racist who simply assumed, without evidence, that Japanese Americans posed a threat of sabotage and espionage. General DeWitt made his final recommendation in favor of internment on February 14, 1942, more than three months after the attack on Pearl Harbor. In support of his recommendation, General DeWitt wrote, "The very fact that no sabotage has taken place to date is a disturbing and confirming indication that such action will be taken."61 DeWitt's inference of a threat from the absence of sabotage rested on his racist assumption that "[t]he Japanese race is an enemy race," and that it was wrong to assume "that any Japanese, barred from assimilation by convention as he is, . . . will not turn against this nation when the final test of loyalty comes." ${ }^{2}$

Rostow points to another indication of General DeWitt's cast of mind: General DeWitt's Final Report, prepared in 1943 and published a year later, mentioned three episodes of shelling the western coast by Japanese submarines. ${ }^{63}$ Two of the three episodes, though, occurred after the removal of Japanese Americans from the West Coast and, as

60. The standard account is PETER IRONS, JUSTICE AT WAR (1983).

61. John L. DeWitT, U.S. ARmy Western Defense Command, Final REPORT: JAPANESE EVACUATION FROM THE WEST COAST, 1942, at 34 (1943), quoted in Rostow, supra note 1, at 521. Here and elsewhere I rely on Rostow's article in the service of the rhetorical goal of showing that information about the decision-maker's state of mind was available roughly contemporaneously with the decisions themselves.

62. Id., quoted in Rostow, supra note 1, at 520-21.

63. Rostow, supra note 1, at 523. 
Rostow pointed out, "These were the only such items in the Final Report which were not identified by date."

The story of the first Red Scare is a bit more complicated. There, the problem was that the policy response should have been known to be ineffective. The reason is bureaucratic. The Department of Justice conducted the raids that rounded up aliens to be processed for deportation. The immigration statutes in place at the time did authorize deportation of aliens who believed in or advocated the violent overthrow of the government, or who were members of organizations that did so. But, the Department of Justice did not control the deportation process. Rather, that was in the hands of the Department of Labor. Department of Justice agents prepared affidavits supporting the arrest, detention, and deportation of aliens, but the Secretary of Labor actually had to decide whether the affidavits and other evidence were sufficient to justify deportation. And, Acting Secretary of Labor Louis Post was much more skeptical about the radical threat than were Department of Justice officials. $^{65}$

Secretary Post believed that a person could be deported as a member of an organization only if the person knew he was a member of the organization. ${ }^{66}$ Further, he believed that many aliens were "members" of Communist parties with unlawful aims only because leaders of the Socialist Party assigned their names to the new Communist parties when radicals split off from the Socialist Party. ${ }^{67}$ Post also insisted that the person know of the organization's illegal aims, and enforced rules against relying on uncounseled confessions and illegally seized evidence such as membership lists. ${ }^{68}$ Post's recalcitrance provoked efforts to remove him from office, but in the end nothing happened precisely because Post was able to show that the Department of Justice actually had very little evidence to support its claims that the aliens it sought to deport were dangerous radicals. ${ }^{69}$ I emphasize that this is not entirely a story of a heroic decision-maker resisting wartime hysteria, although the story does contain such elements. Rather, it is also a story about the inevitable disconnect between one bureaucracy and another-a predictable failure of coordination.

64. Id. Rostow also noted that "[t]hose subsequently arrested as Japanese agents were all white men." Id.

65. Louis F. Post, Deportations Delirium of Nineteen-Twenty: A Personal Narrative of an Historical Official Experience (1923).

66. Id. at 177 .

67. Id. at $178-79$.

68. Id. at 215-22.

69. Id. at 311-12. 
A stronger case can be made for the effectiveness of the actions taken during the second Red Scare. The legal attacks on the Communist Party undoubtedly reduced its organizational effectiveness, and-at least during World War II-U.S. citizens affiliated with the Commumist Party did engage in espionage on behalf of the Soviet Union. Disrupting the Party might have impeded the Soviet Union's espionage efforts somewhat. A complete analysis, though, would require one to examine what might have been done with the resources devoted to undermining the Communist Party had those resources been devoted directly to investigations of espionage. One would have to know, as well, how easy it would have been for the Soviets to develop spies not affiliated with the Commumist Party. I do not know of relevant studies of these questions, although I should note my sense that the investigations of the Communist Party probably were too extensive-consumed too many resources-relative to the role the Party played in espionage, to the availability of other channels of espionage, and to the possibility of deploying the resources more effectively in investigations of espionage directly.

\section{B. Some General Observations: The Relevance of Bureaucracy and Limits on Social Learning}

The story of the first Red Scare suggests a complication with some bearing on defending Korematsu. The decisions we are examining are all taken by government bureaucracies, and an analysis of their effectiveness must take that fact into account. Assume for the moment that General DeWitt actually did believe that Japanese Americans posed a threat of sabotage and espionage (concededly, a belief predicated on racism). He did not act on his own. Rather, he presented his assessment of the threat, and of the possible responses, to bureaucratic superiors. Although General DeWitt's reasons for action may have rested on racist assumptions, the decisions of the higher-ups, relying on DeWitt, were not.

Now, consider the situation from General DeWitt's perspective. $\mathrm{He}$ is the front-line decision-maker, whose actions must receive the endorsement of bureaucratic superiors. Being on the front lines, he may believe that he knows better than his superiors what the true risks are. But, he might fear, were he to present accurate information about those threats, his superiors would mistakenly think that they were small, or that his proposed policy response was inappropriate. So, he presents them with distorted information-knowingly distorted information-to ensure that they will make accurate decisions. 
One aspect of the preceding account of decision-making in uncertain conditions deserves particular note, as a prelude to the next Part's discussion of social learning. At the time decisions are nuade, decision-makers say to the public that the decisions are responses to threats of uncertain size and scope. The decision-makers, or at least some of them, may have information available that suggests rather strongly that the policies being adopted are either ineffective or exaggerated responses to the threats as the decision-makers themselves understand them. But, that information is, understandably, available only to the decision-makers (or, worse, only to some of them). The fact that policies are developed in uncertain times on the basis of information not fully available outside the decision-making bureaucracy may account for the courts' initial acquiescence in the policies, and for the subsequent critical reactions when the previously unavailable information becomes available.

Another consequence of bureaucracy is perhaps so obvious that it might be overlooked. Decision-makers rarely like to admit that they made a mistake, particularly recently. In the present context, the background of Ex parte Quirin ${ }^{70}$ is the most relevant example. In brief: Several Nazi saboteurs landed on the Eastern Seaboard in 1942. One of them immediately went to federal authorities, informing the federal officials of the Germans' mission of sabotage. The officials did nothing for a few days. Then they rounded up the saboteurs, heralding the arrests with press releases touting the effectiveness of the FBl in finding and capturing the saboteurs. Fearing that a public trial would expose the FBl's claims for the nonsense they were, the Departments of the Army and of Justice agreed to prosecute the saboteurs in military tribunals convened for that purpose.

The Supreme Court upheld the constitutionality of tribunals in an action that Justice Frankfurter, one of the leaders inside the Court for validating the government's action, later called "not a happy precedent." 71 The bureaucratic interest in avoiding disclosure of mistakes suggests that the public should be particularly skeptical about claims that government officials know that their actions are justified but unfortunately, for good policy reasons, are unable to disclose the foundation for such claims.

70. 317 U.S. 1 (1942). The best source on the Quirin case is David J. Danelski, The Saboteurs' Case, 1 J. SuP. CT. Hist. 61 (1996).

71. Memorandum, Rosenberg v. United States, from Felix Frankfurter (June 4, 1953) (on file with the Frankfurter Papers, Harvard Law School), quoted in Danelski, supra note 70 , at 80. 
A final general observation also should occasion skepticism, this time about the limits of social learning. The pattern I have described is one that might be called fighting the last war. ${ }^{72}$ That is, the legal world's retrospective evaluation of actions taken the last time around is that those actions were unjustified. Judges and scholars develop doctrines and approaches that preclude the repetition of the last generation's mistakes. Unfortunately, each new threat generates new policy responses, which are-almost by definition-not precluded by the doctrines designed to make it impossible to adopt the policies used last time. And yet, the next generation again concludes that the new policy responses were mistaken. We learn from our mistakes to the extent that we do not repeat precisely the same errors, but it seems that we do not learn enough to keep us from nuaking new and different mistakes. ${ }^{73}$

\section{Some Contemporary Examples}

We can now consider some contemporary examples in light of the patterns I have identified. The first involves the general pattern of retrospective adjustment of our understanding of civil liberties. The second involves the bureaucratic interest in keeping mistakes from the public eye.

We know from the Communist Party cases that a person cannot be convicted of an offense defined as nembership in a proscribed organization, unless the prosecution establishes that the person knew of and agreed with the proscribed goals of that organization. The reason is that people sometimes become members of organizations with mixed goals, legal and illegal, because they agree with and hope to advance the legal goals, and do not know of or seek to change the illegal ones, and that making mere inembership an offense would unduly limit the exercise of those niembers' freedoms of speech and association. But, knowing that we cannot make mere membership a crime, can we nonetheless make paying dues a crime?

72. As Geoffrey Stone puts it, "[O]ne might say that the Court learns just enough to correct the mistakes of the past, but never quite enough to avoid the mistakes of the present." Eternally Vigilant: Free Speech in the Modern Era 8 (Lee. C. Bollinger \& Geoffrey R. Stone eds., 2002).

73. For a similar observation, see David Cole, The New McCarthyism: Repeating History in the War on Terrorism, 38 HARV. C.R.-C.L. L. REV. 1, 3-4 (2003) ("While it has altered slightly the tactics of prevention to avoid literally repeating history, in its basic approach the government today is replaying the mistakes of the past. All we have learned from history is how to mask the repetition, not how to avoid the mistakes."). 
Recent statutes suggest that we can, when they make it an offense to give material support to an organization that has both legal and illegal (terrorist) goals. ${ }^{74}$ In ordinary language, paying dues to an organization with terrorist and non-terrorist goals does give the organization material support. The statute on its face does not require the government to show that the defendant paid the dues knowing that some of the funds would be used to support the illegal goals, perhaps on the theory that, money being fungible, even money paid with the strictest of intentions that it be used for benign activities frees up money to be used for malign ones. If the patterns I have described persist, then we can expect courts to uphold convictions in the face of claims that the government failed to show that the defendant shared the illegal goals. And, we can expect that several years later, courts will begin to require such a demonstration from the government.

Notably, and relevant to much of what follows, one reason for the pattern is that prosecutors are likely to single out the easiest cases for prosecution first, those in which the claim of lack of knowledge of malign goals is quite implausible. But, sometimes-perhaps because of litigation strategy, or because of mistakes in the prosecution-the trial records will not show the defendant's state of mind or knowledge even though it is clear enough what that state of mind was. From a court's point of view, the easiest way to rectify the problem is to say that no evidence of state of mind was really necessary: The government was really trying only to catch true terrorists and those who really did support them, and really did bring before the court such people; the only problem is a small litigation error that the courts will feel inclined to overlook. Then, as weaker cases cone along, courts will begin to realize that prosecutors have taken the statute too far, sweeping up defendants who really were not terrorist supporters in any commonsense way. They then will impose a state-of-mind requirement on the prosecution.

My second example is the government's imposition of secrecy im deportation hearings involving "sensitive" detainees. ${ }^{75}$ Defending the closure of the hearings, the government argued that even the disclosure of the names and addresses of the people whose cases were being heard might provide information useful to terrorists. The argument is that terrorists could examine the names of those the government located, infer the behavior that brought the people to the government's attention

74. See 8 U.S.C. § 1189 (2000); 18 U.S.C. § 2339B (2000).

75. For contrasting decisions on the constitutionality of the secret hearings, see N. Jersey Media Group, Inc. v. Ashcrofi, 308 F.3d 198 (3d Cir. 2002), and Detroit Free Press v. Ashcroft, 303 F.3d 681 (6th Cir. 2002). 
from those names and other information the terrorists could gather about the people, and then adjust their own behavior to keep off the government's radar screen. It is important to acknowledge that this argument is not senseless and may even have substantial merit. But, two points about the argument must also be noted. First, the government's position has the advantage, from a bureaucrat's point of view, of making it difficult for the public to determine whether the government's policy was a sensible response to a realistically evaluated threat. Second, the argument rests on premises for which the evidence cannot be made public by the terms of the argument itself. ${ }^{76}$ In short, just as judges and ordinary citizens must-and probably do-trust executive officials to make appropriate decisions about who to prosecute under laws that could be construed broadly to threaten free expression, so here citizens and judges must trust executive officials to have made realistic evaluations of threats and to have developed sensible policy responses to those threats.

The general point I wish to make here is that the process I have sketched is one in which courts implicitly rely on the good faith of executive officials-here, the officials' good faith effort to prosecute only true terrorists and their supporters-as the unstated basis for overlooking civil liberties problems with the legal positions the executive officials have staked out. These two examples demonstrate the role deference to executive judgment plays in the development of the pattern that I have described. As we will see, deference plays an equally important part in understanding the problem of emergency in constitutional law, the subject of Part IV of this Article.

\section{SOCIAL LEARNING: The Whig Version}

The optimistic view of the pattern I have described is that it demonstrates a valuable form of social learning. ${ }^{77}$ The threat to civil

76. Richard Pildes pointed out an important distinction to me. The government's argument rests on two premises. (1) Terrorists have proven adept at using public information as a basis for adapting their behavior to avoid detection. (2) The aggregate information provided by public disclosure of the names and addresses of subjects of deportation hearing is an example of the type of information covered by premise (1). Clearly, the government could be required to present evidence supporting the first premise, although I would think that, stated at an appropriately general level, the premise is close enough to being obvious that it would need no proof in any particular case. The problem lies in demonstrating the validity of the second premise, and specifically in showing that the information at issue is "enough" like the public information referred to in the evidence regarding the first premise.

77. Jack Goldsmith and Cass Sunstein offer a different version of the Whig 
liberties posed by government actions has diminished in successive wartime emergencies. ${ }^{78}$ We ratchet down our reaction to what we perceive to be a threat each time we observe what we think in retrospect were exaggerated reactions to threats. ${ }^{79}$ To take the obvious example, nothing on the scale of the Japanese internment has yet been proposed during the current situation. ${ }^{80}$ And, no substantial policy of racial profiling has been openly adopted, though expressed support for certain forms of racial (or, nore properly, nationality-based) profiling at airports has increased. ${ }^{81}$

Precisely what, though, has been learned? Consider first the most constitutionally problematic actions actually taken so far, the detentions of two U.S. citizens because of their asserted connections with terrorism. The Bush administration's position is an evolving one. At first the administration claimed that it could detain U.S. citizens indefinitely upon an assertion by executive officials that the citizens

account, attributing the different reactions to Ex parte Quirin and the Bush administration's proposal for military tribunals to broad changes in the legal and popular culture, including growth in general skepticism about government and growth in concern for the rights of the accused. See Jack Goldsmith \& Cass R. Sunstein, Military Tribunals and Legal Culture: What a Difference Sixty Years Makes, 19 Const. COMMENT 261 (2002). This account is not inconsistent with the Whig story I offer, but it is more limited along one dimension, focusing only on one policy rather than on all policy responses to wartime emergencies, and more expansive along another, with its attention to broad cultural changes rather than to the specifics of wartime emergencies. See also Eric L. Muller, 12/7 and 9/11: War, Liberties, and the Lessons of History, 104 W. VA. L. REv. 571 (2002) (noting the limited civil liberties problems with steps taken in the five months after September 11).

78. Other things might be learned from the pattern as well. For example, Korematsu and similar cases might teach us that courts should treat military decisions just as they treat decisions by other bureaucracies, giving no special deference to military judgments. Or, we might learn that our retrospective attention to overestimated threats of danger has obscured our attention to questions about whether policy responses are appropriate even if the threat is properly evaluated.

79. It is worth noting that one part of the process of social learning might be an exaggerated contemporaneous response to present-day policies: Overstated claims that present policies threaten deep incursions on civil liberties might help us learn, over time, that the present policies were unsound, even if not quite as unsound as their present-day critics contend.

80. For testimony about the existence of social learning see FraNCIS BIDDLE, IN BRIEF AUTHORITY 108 (1962) ("[Then-Attorney General Robert] Jackson could not forget his experience in the last war. . . . He remembered the Palmer raids in 1920

...."), id. at 111 ("I was anxious to avoid the hasty and harmful state legislation which had broken out like a rash when the United States entered the First World War."). Biddle was Solicitor General and Attorney General during World War II.

81. For reasons that appear below, I do not regard special screening of foreign visitors born in certain countries as raising interesting questions of domestic civil liberties. See infra text accompanying notes 84-88. 
were unlawful combatants or soldiers in an enemy army, and that such assertions could not be subjected to judicial scrutiny. Later it claimed that the assertions could be reviewed by a court, but only pursuant to an extremely deferential standard, and subject to restrictions on the dissemination of evidence to the detainees themselves. ${ }^{82}$ The administration's present position seems indistinguishable from the position taken by the Roosevelt administration and endorsed by the Supreme Court in Korematsu. But, as I noted at the outset of this Article, Korematsu seems now to be regarded almost universally as wrongly decided. Is it the case, then, that there is simply an illusion of social learning? $?^{83}$

Perhaps the social learming is real. The administration's positions have developed, with the most extreme and problematic ones gradually being replaced-to some extent-by less troubling ones. And, whatever the administration has argued in court, by and large its actions have been more restrained than would be authorized by the administration's asserted legal theories. ${ }^{84}$ One reason for the admimistration's behavior is that those most enthusiastic about expansive presidential power have come to acknowledge the practical political reality that they must scale back their actions, if not their claims. Social learning elsewhere in the society appears to have produced a political dynamic that restrains the admimistration.

An examination of other actions that have been described as threats to civil liberties reveals another dimension of the question of social learning. These actions include detention of resident aliens for suspected visa violations, nondisclosure of the names of those detained, deportations when violations were found, and seemingly intrusive invitations by federal agents to members of Arab American communities to discuss what they knew about potential terrorist activities in their

82. For a description of the administration's positions, see Hamdi v. Rumsfeld, 243 F. Supp. 2d 527 (E.D. Va. 2002), rev'd, 316 F.3d 450 (4th Cir. 2003).

83. Peter J. Spiro, 9/11: Insinuating Constitutional and International Norms, in The Migrations of Threat: National Security After SePTEMBer 11Th (John Tirman ed., forthcoming 2004), points out the important role Congress and public opinion have played in the way social learning has affected policy responses to the September 11 attacks. The concerns I raise in the paragraph accompanying this note arise from legal positions asserted by the Bush administration, suggesting that the fullscale process of social learning has not yet taken hold with respect to the policies at issue.

84. Probably the best example of this restraint is the substantial reduction in the scope of the authority claimed for military tribunals from the initial presidential order authorizing them to the rules developed by the Department of Defense for their conduct. And, of course, as of this writing no military tribunal has been convened anyway. 
communities. ${ }^{85}$ Putting aside the question of whether any of these actions should be treated as threats to civil liberties, I would focus on the fact that the threats have affected almost exclusively non-citizen residents in the United States. Some, it turns out, had violated immigration laws. These law-violators were subjected to deportation when their violations, prior to September 11, would not have led to such action-at least not immediately. The government simply changed its previous policy of respectful consideration of a law-violator's personal circumstances. While perhaps not the policy best suited to a humane government, this does not seem to be a violation of civil liberties.

In some instances, the actions taken might be true violations of civil liberties. But, again, they are violations of the rights of residents who are not U.S. citizens. David Cole argues that such violations might have spill-over effects on the rights of citizens. ${ }^{86}$ That is, once we get accustomed to these actions when taken against non-citizens, we will be more comfortable about extending them to citizens. ${ }^{87}$ That may be true, but the threat to citizens has not yet materialized, except, as I have suggested, in connection with the detentions of citizens as members of an enemy army. In Cole's words: "Measures initially targeted at noncitizens may well come back to haunt us all. ${ }^{88}$ My claim about social learning is that, while the possibility Cole identifies is a real one, its magmitude is smaller than he suggests.

Cole uses the example of the 1920s Red Scare and its extension in the McCarthy era to illustrate his claim. ${ }^{89}$ His thought is that

85. For an overview of these actions, see Cole, supra note 6, at 959-77.

86. See, e.g., id. at 959 ("[W]hat we are willing to allow our government to do to immigrants creates precedents for how it treats citizens.").

87. See Gross, supra note 7, at 48-50 (illustrating how "[t]he longer . . . counter-terrorism laws ... [are] on the statute book, the greater is the likelihood that the extraordinary powers made available to the government under them will infiltrate into the ordinary, normal legal system"); $c f$. id. at 51 (describing various processes by which "One Can Get Used to This").

88. Cole, supra note 6, at 959 (emphasis added); see also JoHN E. FINN, Constitutions in CRISIs: POlitical Violence and the Rule of LAW 54 (1991) ("Desperate measures have a way of enduring beyond the life of the situations that give rise to them."), quoted in Gross, supra note 7, at 39; Gross, supra note 7, at 47 ("We should . . . be aware of the danger that exigencies may lead to a redefinition, over time, of the boundaries of groups, . . . making certain members of the original 'non-terrorist' group into outsiders against whom emergency powers may be 'properly' exercised." (emphasis added)).

89. See Cole, supra note 6, at 995-96. Cole's other example is the extension of the Enemy Alien Act, adopted in 1798 (and still in effect, 50 U.S.C. $\S \S 21-24$ (2000)), to the Japanese internment, and the extension of red-baiting from immigrants in the 1920s to citizens in the McCarthy period. Id. at 990-91, 996. As I have suggested, if the Japanese internment cases are a precedent for anything today, it is a precedent 
McCarthyism shows that we learned that rules applied at first against non-citizens could then be applied to citizens. Similarly, the rules applied today against non-citizens may be applied in the future to citizens. But, one might describe the process of social learming differently. After all, the McCarthy era involved not just the application of rules proscribing various forms of expression, but the development of constitutional doctrine constraining the application of those rules. So, it might be that what we learned is this: Actions that seem constitutionally permissible when taken against non-citizens will be treated as constitutionally problematic when they are taken against citizens. ${ }^{90}$

The social learning process couples learning about exaggerated reactions to perceived threats with a persistent creation of an Othertoday, the non-citizen-who is outside the scope of our concern. ${ }^{91}$ Perhaps, indeed, we are able to discern exaggerated reactions and learn to reduce their reach, only because we are able to displace our concerns on to that Other. ${ }^{92}$ The Whig version of social learning does identify a real process in which government policy in response to emergencies has a decreasingly small range, but a more pessimistic view would direct our attention to the fact that the policy continues to focus on the Other. ${ }^{93}$ Whether any nation could avoid the creation of the Other in situations of emergency, or, perhaps better, how we can restrict the most troubling aspects of the creation of the Other, is probably the central issue in thinking about civil liberties in wartime. The next Part of this Article takes up one aspect, probably the most important, of this issue: the constitutional regulation of emergency powers.

\section{CONSTITUTIONALIZING EMERgENCY POWERS}

Questions about the appropriate degree of deference to executive officials pervade the arguments about the relation between wartime policies and civil liberties. In this final Part, I move to an even more

cautioning against imprudent actions.

90. For a broader critique of Cole's work, see Robert M. Chesney, Civil Liberties and the Terrorism Prevention Paradigm: The Guilt by Association Critique, MiCH. L. REV. (forthcoming 2003) (book review).

91. Cf. Gross, supra note 7, at 44-45 (describing the way in which "[t]he contours of conflict are drawn around groups and communities rather than individuals").

92. Cf. Audrey Macklin, Borderline Security, in The SECURITY OF FreEdom, supra note 7, at 383, 398 (describing "the law's role in producing the alien within").

93. Paul Brietzke suggested to me the mechanism by which social learning is limited: The prior crisis is distinguished from the present one, using criteria that are undeniably reasonable. 
abstract level and consider whether (or how) to regulate the exercise of power in wartime.

My concern here arises from two propositions about constitutional design and implementation. First, constitution designers cannot anticipate all the forms of emergency that will arise and elicit interest among governing elites in expansive exercises of power, ${ }^{94}$ perhaps going beyond the limits placed on power by the constitution designers. At best, constitution designers will use the crises they have experienced to develop some general criteria identifying crises, but even such modeling will inevitably fall short. Second, under modern circumstances the interest in exercising emergency powers will gravitate toward the executive. What, if anything, can constitutional law contribute to thinking about the executive's use of emergency powers? I suggest three possible courses of action: do nothing and leave the regulation of emergency powers to the initial constitution; place legal restraints-in the constitution-on triggering emergency powers and on the powers that can be used in emergencies; or do nothing and acknowledge that executive officials will exercise extraconstitutional emergency powers. All three courses have advantages and disadvantages, and, without purporting to offer a comprehensive analysis, I will suggest that the third course is on balance the best. ${ }^{95}$

\section{A. Emergency Powers Within the Constitution}

The first possibility is to take Justice Hughes's observation in Blaisdell seriously. That is, we would take the origmal constitution as the sole guide for determining whether the exercise of emergency powers is permitted. But, Blaisdell itself illustrates the primary difficulty with this course. The case involved a state law suspending the obligation of debtors to pay their debts during a period of national economic distress. As the dissenters in Blaisdell pointed out, this was

94. In referring to interest among governing elites in exercising this sort of power, I do not mean to suggest that the elites will be unified either on the appropriateness of exercising emergency powers in any particular situation, or on the choice of policies to pursue in that situation. What matters for me is that some significant members of the governing elites will press for the adoption of expansive powers, in the face of a constitution that appears both to fail to anticipate the situation these members of the elites say the nation faces, and to constrain the adoption of policies in response to the perceived emergency.

95. For a broader analysis reaching conclusions that I regard as generally compatible with mine despite some indications otherwise, see Oren Gross, Chaos and Rules: Should Responses to Violent Crisis Always Be Constitutional?, 112 YALE L.J. 1011 (2003). 
precisely the kind of law to which the constitutional ban on state laws impairing the obligation of contracts was directed. In writing the ban the drafters had in mind Rhode Island statutes suspending the obligation of debtors to repay their debts during a period of local (and, to a degree, national) economic distress. ${ }^{96}$

The general point is clear. Constitution drafters anticipate some emergencies, but they fail to anticipate all the ones future decisionmakers will believe they must deal with. Facing a constitution that seems either to fail to authorize or, worse, even to prohibit actions policy-makers deem necessary to respond to the perceived emergency, decision-makers, including courts, will feel pressure to "interpret" the constitution to allow the actions.

Perhaps there is nothing wrong with this sort of creative interpretation. After all, as John Marshall said in one of his great opimions, "we inust never forget, that it is a constitution we are expounding," one that is "to be adapted to the various crises of hunnan affairs." ${ }^{97}$ One might worry, though. Recall the problem of retrospective evaluation discussed earlier. One aspect of such evaluations might be that the perceived crisis was not as severe as it seemed at the time. What is one to make of a decision upholding a policy because it was a permissible response to a crisis? I think there are two possibilities. The Whiggish one is that the exaggerated perception of crisis will discredit the decision as a precedent. The other, more worrisone, is that later policy-makers, including courts, will say, "Well, the action taken then didn't violate the constitution even though there wasn't such a severe threat to social order, so the action under consideration today certainly won't violate the constitution because we face a inore severe threat, and the courts upheld the earlier policy in the face of a less substantial one. ${ }^{98}$

96. As Lino Graglia puts it, in Blaisdell "the Court missed its best, if not its only, chance to hold unconstitutional a law that really was." Lino A. Graglia, Constitutional Law: A Ruse for Government by an Intellectual Elite, 14 GA. ST. U. L. REv. 767, 772 (1998).

97. McCulloch v. Maryland, 17 U.S. (4 Wheat.) 316, 407, 415 (1819) (emphases added).

98. One might argue, for example, that Ex parte Quirin has come to function in this way in contenporary discussions. Cf. Oren Gross, The Normless and Exceptionless Exception: Carl Schmitt's Theory of Emergency Powers and the "Norm-Exception" Dichotomy, 21 CARDOzo L. REv. 1825, 1857 (2000) ("Whenever the boundaries between normalcy and emergency become semitransparent, it is almost invariably the reality of emergency that exerts more mfluence on its counterpart than vice versa."). But see supra text accompanying notes 87-88 (discussing the actual size of the risk that precedents from wartime will be extended to peacetime situations). 
There is a related concern. In addition to serving as a precedent for later, arguably even more problematic decisions, a decision upholding an action as within the powers of a government during an emergency serves to legitimate the action. ${ }^{99}$ It may be a bad thing for a court to validate actions undertaken out of a sense of necessity. ${ }^{100}$

\section{B. Constraining Emergency Powers by Constitutionalizing Them}

Constitution writers can acknowledge the fact that emergencies will arise by attempting to anticipate them and regulate the responses energencies elicit. The U.S. Constitution, for example, contains a provision on emergencies: "The Privilege of the Writ of Habeas Corpus shall not be suspended, unless when in Cases of Rebellion or Invasion the public Safety may require it." ${ }^{101}$ This identifies the occasions on which the protection afforded by the writ of habeas corpus can be suspended-rebellion or invasion-and provides a criterion for determining when the writ can be suspended-public safety. ${ }^{102}$ By its placement in Article I, dealing with congressional power, the Suspension Clause strongly suggests that the power to suspend the writ resides in Congress and not in the President alone. ${ }^{103}$

99. The classic discussion of this effect is Charles L. BLACK, JR., THE People AND THE COURT: JUdiCIAL REVIEW IN A DEMOCRACY 47-51, 56-86 (1960).

100. For additional discussion, see infra text accompanying notes 115-17.

101. U.S. ConST. art. $1, \S 9, \mathrm{cl} .2$.

102. Other constitutions provide a more extensive list of occasions and criteria, and identify substantive constitutional protections that can be suspended during periods of emergency. These provisions are sometimes described as following a "reference model" for emergency powers. See, e.g., JoAN FITZPATRICK, HuMAN RIGHTS IN CRISIS: The INTERnational SySTEM for Protecting Rights DURING STATES OF EMERGENCY 21 (1994) (drawing the term from a report by Nicole Questiaux to the United Nations SubCommission on the Prevention of Discrimination and Protection of Minorities). My view is that the Suspension Clause is all that is needed to protect substantive constitutional rights against violation: Guaranteeing the existence of a remedy for claimed constitutional violations is equivalent to guaranteeing substantive rights themselves.

103. Article 48 of the Weimar Constitution is an example of a more comprehensive emergency powers provision. It provided:

If public safety and order in the German Reich is materially disturbed or endangered, the President of the Reich may take the necessary measures to restore public safety and order . . . . To this end he niay temporarily suspend, in whole or in part, the fundamental rights [to inviolability of the person, inviolability of domicile, secrecy of communication, freedom of opinion and expression, and inviolability of propertyl.

The President of the Reich must immediately inform the Reichstag of all measures adopted by the authority of . . . this article. These measures shall be revoked at the demand of the Reichstag. 
The Suspension Clause provides an example as well of some problems associated with seeking to constrain emergency powers by addressing them in a constitution. ${ }^{104}$ The primary difficulty is the fundamental one, that constitution writers cannot anticipate all the occasions on which governing elites will think that it is good policy to invoke emergency powers, nor can they specify in detail all the criteria regulating such invocations. ${ }^{105}$ For example, was the attack on the World Trade Center towers an "invasion" within the meaming of the Suspension Clause? If so, is the threat of an invasion, in the forn of some similar attack, a ground for suspending the writ?

The fact that emergencies arise with unanticipated characteristics means that such emergencies will place pressure on whatever constitutional provisions there are. ${ }^{106}$ If the attack on the World Trade Center towers was not exactly an invasion of the sort the framers had in mind, still, governing elites may think, it is enough like such an invasion to mean that the Constitution permits suspension of the writ. And, if that attack is enough like a (true) invasion, so the threat of another attack might be enough like a (true) invasion, and so forth. ${ }^{107}$

CONSTITUTION OF THE WEIMAR REPUBlic art. 48 (German Information Center, New York, trans.), reprinted in THE CONSTITUTIONS of EUROPE 112-13 (E.A. Goerner ed., 1967).

104. Committing the decision to suspend the writ to Congress seems to deal with the problem of aggressive assertions of executive authority in emergencies. But, the commitment may be illusory. Perhaps the Constitution can be read, as Lincoln thought it could, to authorize the President to suspend the writ as long as he seeks congressional approval as speedily as possible thereafter. Even more, Presidents will almost always be able to identify some statute that, they will say, authorizes them to suspend the writ. A court might eventually find that the President's interpretation of the statutes is erroneous, but in the meantime the writ will have been effectively suspended by action of the President alone.

105. See, e.g., Gross, supra note 98, at 1827 ("The exception is comprised of sudden, urgent, usually unforeseen events or situations that require immediate action, often without time for prior reflection and consideration-i.e., without allowing for preplanned responses.").

106. Alex Aleinikoff suggested to me the possibility of an unrestricted power to derogate from constitutional protections. Such a power would not raise the difficulties I describe here. There would be no need to stretch constitutional language to cover unanticipated emergencies, because the power would be unrestricted as to the occasions on which it can be invoked. And (perhaps), the possibility of inappropriate invocation would be limited by the formulation of the power as one of derogation, that is, as a power to override what remain permanent and fundamental constitutional norms, and limited as well by the political costs associated with asserting a need to override constitutional protections. I am skeptical about the possibility of constitution drafters accepting an unrestricted power to derogate, because I believe they will find the very idea of unrestricted power to be inconsistent with constitutionalism itself.

107. If the threat of another attack similar to those of September 11 counts as an 
The general point is obvious: Constitutional provisions that purport to regulate the invocation of emergency powers will be subject to pressure on precisely those occasions when the provisions seem not to address the situation facing policy-makers, which are also precisely the occasions when restrictions on the invocation of emergency powers would seem most important. Including emergency powers provisions in a constitution might well be futile, because those powers will be exercised no matter what the constitution says.

But, there is a further point. Governments operating after the invocation of emergency powers provisions are sometimes called regimes of exception. ${ }^{108}$ That term properly recalls the proposition stated by German legal theorist Carl Schmitt that the person who has the power to invoke the exception is the true sovereign in a nation. ${ }^{109}$ Further, Schmitt argued that the (liberal) rule of law could not-either conceptually or practically-limit a nation's response to perceived emergencies. Schmitt initially distinguished between an absolute form of emergency rule, in which the invocation and use of emergency powers was completely unconstrained, and a rule-of-law form, in which the law identified the occasions for invoking emergency power, the criteria for doing so, and the precise types of action that emergency power justifies. ${ }^{110}$ A year later Schmitt rejected this distinction, arguing that only the first form of emergency power is available because emergencies are situations in which a nation's very existence is perceived to be at stake, and the rule of law cannot constrain a nation's efforts to survive.

As I have emphasized, regimes of exception will arise; the only real question is how to locate them in relation to the nation's constitution. Or, put another way, was Schmitt right the first time or the second? Consider one aspect of emergency powers under Schmitt's first view. Constitutional provisions dealing with emergency powers place regimes of exception within the constitutional order. Constitutional provisions dealing with emergency powers provide a language of justification for the invocation of emergency powers, even though the precise language used in the constitution may be inapt for the occasions on which emergency powers are invoked. The provisions provide executive

invasion, then why would not the threat of an attack from Iraq?

108. See, e.g., Brian loveman, The Constitution of Tyranny: Regimes of EXCEPTION IN SPANISH AMERICA (1993).

109. Carl Schmitt, Political Theology: Four Chapters on the Concept OF SOVEREIGNTY 1 (George Schwab trans., MIT Press 1988) (1922). Schmitt believed that his theory justified the actions of the Nazi regime.

110. For a discussion of the change in Schmitt's views, see Gross, supra note 98 , at $1840-41$. 
officials with a fig-leaf of legal justification for expansive use of sheer power. What appears to be emergency power limited by the rule of law is actually unlimited emergency power. ${ }^{111}$

Further, courts may well succumb to the understandable pressure to rationalize the inevitable with the constitution; judges as members of the governing elites will feel the need for emergency powers that other members of those elites do, ${ }^{112}$ and judges as judges will feel some need to make what seems necessary be lawful as well. ${ }^{113}$ But, in explaining why the current circumstances fit within constitutional provisions designed for other circumstances (as in treating the attacks on the World Trade Center or the threat from Iraq as an "Invasion"), judges may make the exceptional the normal. As David Dyzenhaus has put the point in a related context, "one cannot, as Carl Schmitt rightly argued, confine the exception. If it is introduced into legal order and treated as such, it will spread."114 The temporary will be made permanent, threatening civil liberties well beyond the period of the emergency. ${ }^{115}$

\section{Emergency Powers Outside the Constitution}

Dyzenhaus argues that judges can domesticate emergency powers by subjecting their exercise to the ordinary requirements of the rule of law. Other authors-taking the position Schmitt initially did-argue that well-designed emergency powers provisions can avoid the difficulties

111. For a discussion of problems arising from the inclusion of emergency powers in Latin American constitutions, see Gabriel L. Negretto \& José Antonio Aguilar Rivera, Liberalism and Emergency Powers in Latin America: Reflections on Carl Schmitt and the Theory of Constitutional Dictatorship, 21 CARDozo L. REv. 1797, 1803-09 (2000). See also Loveman, supra note 108, at 23 ("Generally, a regime of exception ... legitimizes the drastic measures adopted to meet natural or man-made threats to the existing political and social order. ${ }^{n}$ ).

112. Although perhaps fewer judges than executive officials will feel that need, or perhaps judges will feel the need to a lesser extent.

113. As David Dyzenhaus puts it, "Judges are unwilling to say that their role as guardians of the rule of law is either at an end or greatly reduced." David Dyzenhaus, Humpty Dumpty Rules or the Rule of Law: Legal Theory and the Adjudication of National Security, AUSTL. J. LEGAL PHIL. (forthcoming); see also IYER, supra note 25, at 63 (referring to "an unfortunate tendency on the part of many judges to adopt an attitude of relative passivity in times of political crises ${ }^{n}$ ).

114. Dyzenhaus, supra note 113.

115. See David Dyzenhaus, The Permanence of the Temporary: Can Emergency Powers be Normalized?, in THE SECURITY OF FREEDOM, supra note 7, at 21. Dyzenhaus notes that the title of his chapter comes from a work written by two South Africans dealing with emergency powers under apartheid. Id. at 23 (citing A.S. Mathews \& R.C. Albino, The Permanence of the Temporary-An Examination of the 90- and 180-Day Detention Laws, 83 S. AFR. L.J. 16 (1966)). 
that have arisen with existing ones. ${ }^{116}$ As I see it, the difficulty with these prescriptions is empirical rather than conceptual. ${ }^{117}$ The U.S. experience that I have sketched, even in the optimistic Whig version, gives little reason to hope that judges will in fact limit einergency powers in light of constitutional norms rather than interpret the constitution to accommodate exercises of emergency powers. ${ }^{118}$

Dyzenhaus hints at another path. Decision-makers might treat emergency powers as extraconstitutional, an understandable departure from norms of legality. Justice Robert Jackson's opimion in Korematsu suggests how courts could conceptualize emergency powers in this way. Jackson wrote:

[I] $\mathrm{f}$ we cannot confine inilitary expedients by the Constitution, neither would I distort the Constitution to approve all that the military may deem expedient.

... [A] judicial construction of the due process clause that will sustain this order is a far more subtle blow to liberty than the promulgation of the order itself. . . . [O]nce a judicial opinion rationalizes such an order to show that it conforms to the Constitution, or rather rationalizes the Constitution to show that the Constitution sanctions such an order, the Court for all time has validated ... . [a] principle [that] lies about like a loaded weapon ready for the hand of any authority that can bring forward a plausible claim of an urgent need. . . .

116. See, e.g., Negretto \& Aguilar Rivera, supra note 111, at 1809 (arguing that "a poorly conceived institutional design was one of the major causes for the abuse of emergency powers in Latin America").

117. To some extent my position rests in part on the proposition that constirutional provisions-both substantive provisions and those dealing with emergency powers-are sufficiently indeterminate that judges will be able to reconcile their urge to rationalize the emergency and the constitution without feeling a strain on their professional responsibility for enforcing the rule of law. For a discussion of the relation between Carl Schmitt's commitment to a much stronger version of legal indeterminacy and his position on emergency powers, see Gross, supra note 98, at 1830-31.

118. And even this way of putting the point presupposes a position on the question of what the constitution "truly" means. See supra Part II.C. Dyzenhaus writes:

The government introduces legislation that is inherent suspect from the perspective of the rule of law, but avoids . . . provisions that seem in flagrant violation of rule of law principles. The dirty work is done by those charged with implementing the law and the government expects that judges who hear challenges to the validity of particular acts will put aside their role as guardians of the rule of law because in issue is the security of the state.

Dyzenhaus, supra note 113, at 29-30. 
$\cdots$

.. The chief restraint upon those who command the physical forces of the country, in the future as in the past, must be their responsibility to the political judgments of their contemporaries and to the more judgments of history. ${ }^{119}$

Jackson does not quite make the point I extract from his opinion, which is that it is better to have emergency powers exercised in an extraconstitutional way, so that everyone understands that the actions are extraordinary, than to have the actions rationalized away as consistent with the Constitution and thereby normalized. ${ }^{120}$ One might call this a claim that the actions have an extraconstitutional validity, one that the courts cannot endorse but that is consistent with the persistence of the constitutional regime. ${ }^{121}$

Treating emergency powers as extraconstitutional has another advantage..$^{122}$ Decision-makers can then understand that they should regret that they find themselves compelled to mvoke eniergency powers. ${ }^{123}$ Once the emergency has passed they should not only revert

119. 323 U.S. at 244-47 (Jackson, J., dissenting).

120. Doctrinally, we might want to say that the constitutionality of exercises of emergency powers presents a political question. The canonical formulation in Baker $v$. Carr, 369 U.S. 186 (1962), does not support that conclusion well. The Suspension Clause seems to preclude a holding that determining when an emergency exists is committed by the text to another branch, although perhaps a creative interpretation of the Suspension Clause would allow the Court to find that it commits determination of when an "Invasion" exists to the political branches. Cf. Nixon v. United States, 506 U.S. 224 (1993) (holding that the constitutional provision giving the Senate the sole power to try impeachments also gives the Senate the power to determine what proceedings constitute a trial). In light of Powell v. McCormack, 486 U.S. 395 (1969), it would seem easy to discover "judicially manageable standards" for determining whether the nation was subject to an "Invasion" within the meaning of the Suspension Clause. Perhaps one could shoehorn the question into the category of cases raising "the potentiality of embarrassment from multifarious pronouncements by various departments on one question." Baker, 369 U.S. at 686 . But, in the end, Jackson's instinct is one that fits uneasily into any doctrinalized approach to the political questions idea. For a discussion of the doctrinalization of the idea, see Mark Tushnet, Law and Prudence in the Law of Justiciability: The Transformation and Disappearance of the Political Question Doctrine, 80 N.C. L. REv. 1203 (2002).

121. I am indebted to Wayne Moore for the term "extraconstitutional validity." Moore suggests as well that the first two approaches I described could be called constitutional legality and extra-legal constitutional validity.

122. Of course it has the obvious disadvantage of providing no brakes within law on the exercises of emergency power.

123. That is why I describe the invocation of emergency powers as an understandable departure from legality rather than a justified one. A justified departure from legality would not be regrettable. Wayne Moore suggests that we might 
to the norms of legality that were suspended during the emergency, but should do what they can to make reparation for the actions they took. ${ }^{124}$ Here too Lincoln should be our guide, for among his observations in his Second Inaugural Address, delivered in anticipation of a successful conclusion of the Civil War, was the injunction that we "strive on ... to bind up the nation's wounds." 25

\section{CONCLUSION}

Have I truly "defended" Korematsu? In one sense, yes. I have tried to explain how decision-makers faced with what they understood to be a threat to the nation might engage in actions that in retrospective seem quite unjustified. I have suggested that those actions should look different, not only to those who evaluate them in the future, but to ordinary citizens and judges at the time the actions are taken. Judges should refrain from giving in to an understandable urge to make exercises of emergency powers compatible with constitutional norms as the judges articulate them, to avoid normalizing the exception. And ordinary citizens should take a stance of watchful skepticism about claims from executive officials that the actions the officials take are in fact justified by, and sensible policy responses to, threats to national security. ${ }^{126}$ This is particularly true when the officials assert that the nature of the threat makes it impossible for them to disclose fully the reasons for the actions they take. The officials may be right, which is why ordinary citizens should not be flatly outraged by the actions, ${ }^{127}$ but there is a good chance that they are wrong, which is why we should be skeptical about their assertions and careful about accepting them.

distinguish between the decision-maker, who might not be in a position to regret making the decisions they do, and others, such as Supreme Court justices, who might regret being required to allow others to make extraconstitutional decisions.

124. The Civil Liberties Act of 1988, Pub. L. No. 100-383, 102 Stat. 903 (codified as amended at 50 U.S.C. App. $\S \S 1989 \mathrm{~b}$ to $1989 \mathrm{~b}-9$ (2000)), can then be understood as an expression of the view developed here. See also William A. FISCHEL, REgUlatory TAKINGS: LAw, ECONOMICS, AND POLICY $\S 3.15$ (1995) (suggesting that policies expressing regret are more easily adopted the longer the time-span between the violation and the policies' adoption). Peter Schuck suggested to me another policy response: an insistence on maintaining records and making them public on an accelerated schedule, to shorten the time before social learning begins.

125. President Abraham Lincoln, Second Inaugural Address (Mar. 4, 1865), in SPEECHES AND WRITINGS 1859-1865, at 687 (D. Fehrenbacher ed., 1989).

126. I am aware of the significance of my using the term citizens here.

127. Except insofar as the process of social learning I described requires that some citizens publicly characterize the actions as outrageous. See supra note 79. 
